\title{
Election of President
}

\section{Notice to Fellows and Members}

Fellows and Members are reminded of their rights under the Bye-Laws and Regulations, as follows:

\section{Bye-Law XI}

The President shall be elected annually from among the Fellows.

\section{Regulation XI}

(1) As soon as may be practicable after the first day of June in any year the Council shall hold a nomination meeting and shall at such meeting nominate not less than one candidate and not more than three candidates.

(2) Between the first day of June in any year and the date which is four clear weeks after the nomination meeting of the Council, written nominations, accompanied in each case by the nominee's written consent to stand for election, may be lodged with the Registrar, provided that each such nomination is supported in writing by not less than twelve Members of the College who are not members of the Council.

(3) An election by ballot shall be held in accordance with the provisions of the Regulations.

The nominating meeting of the Council will be held on 21 October 1998 and the last date for receiving nominations under (2) above will, therefore, be 18 November 1998. Dr Robert Kendell is in his third year of office as President and is, therefore, not eligible for re-election.

\section{FORTHCOMING FROM GASKELL}

\section{ClinicalTopics in Psychotherapy}

\author{
Edited by Digby Tantam
}

The focus of this book is on specific conditions in which psychotherapy is the main treatment currently in use. Common syndromes which patients present to the psychotherapist and to general psychiatrists are covered. Contributors provide a succinct review of what treatment works in each condition, and how it works. Some of the chapters have been published previously in the British Journal of Psychiatry.

\section{READERSHIP:}

- $\quad$ psychotherapists, general psychiatrists, general practioners, and all those whose profession involves the provision of psychological treatment

October 1998, £30.00, 304pp, Paperback, ISBN 1901242226

\section{Royal College of Psychiatrists, 17 Belgrave Square, London SW1X 8PG} TEL: +44 (0) 171235 2351, EXT 146 FAX: +44 (0) 1712451231 http://www.rcpsych.ac.uk 